\title{
SKEMA POLA PEREMAJAAN KELAPA SAWIT SWADAYA YANG BERKELANJUTAN DI PROVINSI JAMBI
}

\author{
Mirawati Yanita1), Ernawati HD2), Zulkifli Alamsyah3), Dompak Napitupulu4), Gina fauzia5) \\ 1,2,3,4,5)Dosen Jurusan Agribisnis Fakultas Pertanian Universitas Jambi \\ Email : mirawatiyanita@unja.ac.id
}

\begin{abstract}
ABSTRAK
Pengembangan kelapa sawit antara lain memberikan manfaat dalam peningkatan pendapatan petani dan masyarakat, produksi yang menjadi bahan baku industri pengolahan yang menciptakan nilai tambah di dalam negeri. Namun masih banyak kelapa sawit yang telah memasuki umur tua atau rusak belum diremajakan dengan berbagai alasan. Penelitian ini bertujuan untuk mengidentifikasi pola peremajaan kelapa sawit yang berkelanjutan yang ada di provinsi Jambi. Melalui Focus Group discussion dicari pola mana yang akan ditawarkan kepada pekebun swadaya dalam melakukan peremajaan kelapa sawit yang berkelanjutan dengan tidak mengessampingkan sumber pendapatan selama melakukan peremajaan. Hasil penelitian menunjukkan terdapat 4 skema pola peremajaan kelapa sawit yang berkelanjutan di provinsi Jambi, yakni, melalui pola kemitraan, swadaya murni, inisiasi PEMDA dan koperasi.
\end{abstract}

Kata Kunci: Kelapa sawit, Pola Peremajaan, Berkelanjutan

\section{PENDAHULUAN}

Komoditas kelapa sawit telah menjadi salah satu sumber pendapatan nasional paling penting dalam pembangunan sistem ekonomi Indonesia. Sejak 2009, Indonesia telah menjadi produsen minyak kelapa sawit terbesar di dunia (Krishna et al, 2017; Clough, 2016). Mempromosikan kelapa sawit telah meningkatkan pendapatan petani dan pembangunan ekonomi (Feintrrenie et. al., 2010; Rist et al, 2010; Lee at. al., 2014; Castiblanco, 2015; Gatto, 2017; Jelsma et. al., 2017). Meskipun efek dari budidaya kelapa sawit bervariasi dari waktu ke waktu (Kubitza, 2018). Pengembangan kelapa sawit antara lain memberikan manfaat dalam peningkatan pendapatan petani dan masyarakat, produksi yang menjadi bahan baku industri pengolahan yang menciptakan nilai tambah di dalam negeri. Gambar 1 menunjukkan perbandingan luas area kelapa sawit menurut status pengusahaan tahun 2017.

Data menunjukkan bahwa kelapa sawit ditanam secara komersial di setidaknya 25 di antara 34 provinsi di Indonesia (BPS, 2017) dan memberikan kontribusi sebesar Rp 260 triliun (2,75\%) dari pendapatan Nasional Indonesia di tahun 2016. Pengusahaan kelapa sawit saat ini menyerap lebih dari 5,5 juta tenaga kerja di sektor on farm (perkebunan) dan memberikan devisa sebesar 287 trilyun pada tahun 2017. Berdasarkan provinsi, dari produksi nasional pada tahun 2017 Provinsi Jambi menyumbang minyak sawit sebesar 5,87 persen dari produksi nasional dengan luas lahan mencapai 8,54 persen dari luas lahan Nasional yang memasok 57 Pabrik Kelapa Sawit (PKS) di Provinsi Jambi. Sektor Perkebunan di Provinsi Jambi diusahakan oleh 660.198 Kepala Keluarga petani. Sektor ini menyumbang PDRB Provinsi sebesar 17,2 persen pada tahun 2017. Dimana pekebun yang terlibat dalam pengusahaan kelapa sawit sebanyak 32 persen. Menurut Dinas Perkebunan Provinsi Jambi (2018) bahwa dari luas areal sebesar 791.025 hektar kelapa sawit, 66,66 persen diusahakan oleh Pekebun Rakyat (PR), 3,01 persen Perkebunan Besar Negara (PBN) dan sisanya oleh Perkebunan Besar Swasta (PBS).

Pengusahaan kelapa sawit tersebar di 8 kabupaten di Provinsi Jambi. Dimana kabupaten yang memiliki luas perkebunan rakyat paling besar adalah Kabupaten Muaro Jambi dengan kontribusi sebesar 21,7 persen, diikuti Kabupaten Tanjung Jabung Barat dan Kabupaten Merangin berturut-turut sebanyak 19,8 persen dan 13,1 persen. Kondisi tanaman kelapa sawit rakyat yang ada di Provinsi Jambi sebanyak 23,43 persen merupakan Tanaman Belum Menghasilkan (TBM), Tanaman Menghasilkan (TM) 73,06 persen dan sisanya sebanyak 3,5 persen dalam keadaan tua dan rusak. Luas kebun kelapa sawit rakyat 526.822 
$\mathrm{Ha}$, dan kondisi tanaman yang sudah masuk masa peremajaan $63.114 \mathrm{Ha}$. Target peremajaan melalui Kerangka BPDPKS untuk Provinsi Jambi seluas $20.000 \mathrm{Ha}$. Tabel 1 menunjukkan target tanaman kelapa sawit yang harus dilakukan peremajaan di Provinsi Jambi (Dinas Perkebunan Provinsi Jambi, 2019).

Tabel 1. Target Peremajaan Tanaman Kelapa Sawit di Provinsi Jambi Tahun 2017 - 2019

\begin{tabular}{|c|c|c|c|c|}
\hline \multirow{2}{*}{ No } & \multirow{2}{*}{ Kabupaten } & \multicolumn{3}{|c|}{ Luas Lahan (Ha) } \\
\hline & & 2017 & 2018 & 2019 \\
\hline 1 & Merangin & 685 & 4.000 & 4.234 \\
\hline 2 & Bungo & 1.000 & $1.295,95$ & 1.560 \\
\hline 3 & Muaro Jambi & 1 & 3.500 & 3.556 \\
\hline 4 & Tanjung Jabung Barat & 800 & 3.210 & 3.267 \\
\hline 5 & Batang Hari & 760 & $2.027,32$ & 2.217 \\
\hline 6 & Tebo & 0 & 1.740 & 2.379 \\
\hline 7 & Sarolangun & 0 & 0 & 1.038 \\
\hline 8 & Tanjung Jabung Timur & 0 & 0 & 0 \\
\hline & Jumlah & 3.246 & $15.773,27$ & 18.231 \\
\hline
\end{tabular}

Sumber: Dinas Perkebunan Provinsi Jambi, Tahun 2019

Pemanfaatan dana dari BPDPKS baru terealisasi mulai tahun 2018 di KUD Hitam Jaya seluas 139,18 Hektar dengan nilai Rp. 3.479.500.000 dan sampai Agustus 2019 baru terealisasi seluas 2.309,3483 Hektar atau senilai Rp.57.733.707.500. Tabel 2 menunjukkan realisasi KUD, Gapoktan atau Kelompok Tani yang telah memperoleh dana PSR tahun 2018 dan tahun 2019. Berdasarkan Tabel 1 realisasi dan target yang ditetapkan sangat jauh sekali. Target tahun 2019 luas lahan yang harus diremajakan seluas $18.251 \mathrm{Ha}$. Artinya baru 6,19\% yang berhasil direalisasikan. Menjelang akhir tahun 2019 sulit rasanya untuk mencapai $50 \%$ saja realisasi peremajaan. Hasil temu mitra BPDPKS yang telah memperoleh dana tanggal 18 - 19 Januari 2019 di Jambi, diperoleh bahwa masih banyak petani yang mengalami kesulitan untuk merealisasikan peremajaan serta untuk memulai peremajaan tersebut. Selain itu syarat atau kriteria untuk mendapatkan dana BPDPKS juga menyulitkan petani untuk mengajukan proposal dana peremajaan. Hasil penelitian dana BPDPKS tahun lalu, dari 640 pekebun sampel di 8 kabupaten, hanya 34 persen yang tergabung dalam kelembagaan, sisanya tidak berafiliasi dengan kelembagaan manapun. Alasan tidak bergabung dalam kelompok tani ataupun lembaga seperti koperasi adalah sebagian besar petani beranggapan KUD tidak berjalan dengan baik dikarenakan pengurusan dana petani tidak dilakukan secara transparan dan banyaknya kelompok tani yang tidak aktif dan hanya terbentuk pada saat adanya bantuan dari pemerintah. Berdasarkan fenomena di atas skema pola peremajan apa saja yang dapat menjadi alternatif pekebun kelapa sawit dalam melakukan peremajaan yang berkelanjutan.

\section{METODE PENELITIAN}

\section{Ruang Lingkup dan Tempat Penelitian}

Ruang lingkup penelitian adalah komoditas kelapa sawit yang terdapat di 8 kabupaten penghasil kelapa sawit swadaya di provinsi Jambi. Waktu penelitian dimulai dari Juli - September 2019.

\section{Jenis dan Metode Pengumpulan Data}

Data yang dikumpulkan merupakan data primer dan data sekunder. Pengumpulan data primer yang dilakukan dalam penelitian ini menggunakan metode Focus Group Discussion (FGD) dan wawancara terstruktur dan menggunakan studi dokumentasi. Menurut Fathoni (2005), wawancara adalah teknik pengumpulan data melalui proses tanya jawab lisan yang berlangsung satu arah, artinya bahwa pertanyaan datang dari satu pihak yang mewawancarai dan jawaban diberikan oleh yang diwawancarai. Sedangkan studi dokumentasi adalah teknik pengumpulan data dengan mempelajari catatan-catatan mengenai. Pengumpulan data sekunder berasal dari instansi terkait seperti dinas perindustrian perdagangan serta Dinas Ketahanan Pangan, Dinas Pertanian dan atau dokumen profil perusahaan 
penggilingan. Metode pengambilan sampel yang digunakan adalah pengambilan sampel non acak yaitu teknik Purposive Sampling. Sampel yang dipilih merupakan ahli atau expert dalam hal kelapa sawit yang ada di provinsi Jambi, meliputi para stakeholder, pengusaha, pihak koperasi dan APKASINSO

\section{Metode Analisis Data}

Metode penelitian yang digunakan dalam penelitian ini adalah metode deskriptif Menurut Hikmat (2011), metode deskriptif adalah metode penelitian untuk membuat gambaran mengenai situasi atau kejadian, sehingga berkehendak mengadakan akumulasi data dasar. Analisis data dilakukan secara kualitatif. Analisis kualitatif untuk mendeskripsikan skema pola peremajaan kelapa sawit pekebun swadaya yang berkelanjutan di Provinsi Jambi. Analisis deskriptif mengubah kumpulan data mentah menjadi bentuk yang mudah dipahami dan dalam bentuk informasi menjadi bentuk yang lebih ringkas. Pendeskripsian dari hasil observasi merupakan ciri khas dari analisis deskriptif (Wibisono, 2003). Setelah melakukan observasi dan wawancara melalui FGD, kemudian menggambarkan atau mendeskrisikan data yang didapat mengenai skema pola peremajaan kelapa sawit tersebut.

\section{HASIL DAN PEMBAHASAN}

\section{Gambaran Umum Kelapa sawit di Provinsi Jambi}

Provinsi Jambi merupakan salah satu provinsi yang mengandalkan sektor pertanian untuk menigkatkan pendapatan, meningkatkan taraf hidup petani, dan memperluas lapangan kerja. Salah satu subsektor pertanian yang dikembangkan adalah subsektor tanaman perkebunan khususnya tanaman kelapa sawit. Provinsi Jambi memiliki luas perkebunan kelapa sawit 663.500 Ha pada tahun 2016 yang sebagian besar lahan tersebut merupakan perkebunan rakyat dengan luas $467.573 \mathrm{Ha}(70,47 \%)$, perkebunan besar negara dengan luas $24.062 \mathrm{Ha}(3,62 \%)$ dan perkebunan swasta dengan luas $171.865 \mathrm{Ha}(25,90 \%)$. (Direktorat Jenderal Perkebunan, 2017). Kelapa sawit merupakan salah satu komoditi unggulan di Provinsi Jambi yang memiliki peranan potensial yang sangat strategis sebagai sumber pendapatan masyarakat, mampu menyerap tenaga kerja, dengan prospek pasar yang baik dan layak untuk dikembangkan sebagai komoditi ekspor. Pengembangan perkebunan rakyat merupakan pendekatan dari pengembangan perkebunan kelapa sawit, maka dari itu pengembangan perkebunan kelapa sawit tidak hanya diusahakan sebagai perkebunan besar namun diusahakan juga pada perkebunan rakyat. Perkebunan rakyat merupakan usaha tanaman perkebunan yang dimiliki atau dikelola oleh perorangan dan tidak berbadan hukum.

Luas lahan kelapa sawit terbesar di Provinsi Jambi yaitu berada di Kabupaten Muaro Jambi (97.692 Ha) dengan produktivitas 3.4 ton/ha dan Kabupaten Merangin berada diposisi ke tiga dengan luas $58.929 \mathrm{Ha}$. Namun demikian produktivitas yang dihasilkan Kabupaten Merangin merupakan produktivitas tertinggi di Provinsi Jambi yaitu mencapai 3.84 ton/ha. Menurut Dinas Perkebunan Provinsi Jambi (2017), produktivitas kelapa sawit di Kabupaten Merangin terus mengalami penurunan. Pada tahun 2014 produktivitas kelapa sawit di Kabupaten Merangin sebesar 3,86 ton/ha dan menurun pada tahun 2016 menjadi 3,84 ton/ha hal tidak terlepas dari peningkatan luas areal tanaman kelapa sawit tua pada tahun 2016 mencapai 2.975 Ha yang sebelumnya pada tahun 2014 hanya mencapai $1 \mathrm{Ha}$. (Dinas Perkebunan Provinsi Jambi, 2017).

Program Peremajaan Sawit Rakyat (PSR) adalah upaya pengembangan perkebunan dengan melakukan penggantian tanaman tua atau tidak produktif dengan tanaman baru, baik secara keseluruhan maupun bertahap. Pemerintah menargetkan peremajaan 185 ribu hektar kebun sawit rakyat nasional di tahun 2018. Untuk menyukseskan program tersebut, pemerintah memberikan bantuan dana Rp 25 juta per hektar kepada para petani melalui Badan Pengelola Dana Keuangan Kelapa Sawit (BPDPKS) dan Kementerian Pertanian dengan pertimbangan umur tanaman yang akan dan telah melampaui umur ekonomis yaitu sekitar 25 tahun, tanaman tua dengan produktivitas rendah atau di bawah 10 ton/ha/tahun yang mengakibatkan keuntungan yang diperoleh petani menurun. Menurut Anggreany (2015), Peremajaan kelapa sawit seharusnya telah terlaksana secara keseluruhan, namun hanya sebagian kecil petani yang sudah melakukannya. Hal ini disebabkan oleh permasalahan yang dihadapi petani seperti luas lahan 
perkebunan yang tergolong sempit, masa tunggu hasil dari peremajaan hingga dapat menghasilkan yang tergolong cukup lama, keterbatasan modal untuk melakukan peremajaan dan ketakutan petani kehilangan mata pencaharian apabila tanaman kelapa sawit yang dimiliknya diremajakan. Program peremajaan kelapa sawit yang dilaksanakan tentunya membutuhkan biaya yang tidak sedikit, fakta ini merupakan permasalahan yang dihadapi oleh petani dalam melakukan peremajaan. Masalah ekonomi lainnya adalah biaya yang dibutuhkan petani selama masa peremajaan baik untuk membiayai kebutuhan konsumsi keluarganya maupun untuk biaya peremajaan. Hal tersebut mempengaruhi petani agar mencari strategi dalam memenuhi kebutuhan keluarga dan biaya lainnya selama peremajaan.

\section{Skema Pola Peremjaan Kelapa sawi Pekebun Swadaya yang Berkelanjutan di Provinsi Jambi}

Peremajaan adalah pergantian tanaman tua yang tidak ekonomis lagi dengan tanaman baru. Pertimbangan utama dilakukannya peremajaan kelapa sawit karena umur tanaman lebih dari umur ekonomis atau sekitar 25, namun tidak jarang umur ekonomis hanya mencapai 19 tahun yang memiliki produktivitas semakin menurun, sehingga dipandang tidak lagi memberikan keuntungan secara ekonomis bahkan bisa merugikan. Tanaman yang berproduksi rendah sebagai akibat dari umur tanaman yang sudah tua dan dianggap kurang menguntungkan.Kesulitan panen juga dijadikan sebagai pertimbangan dalam menentukan saat petani harus melakukan peremajaan kebun kelapa sawit miliknya. Tanaman kelapa sawit yang sudah tua umumnya memiliki pohon yang tinggi sehingga menyulitkan petani pada saat proses pemanenan, serta efektivitas dan efisiensi panen menjadi rendah karena biaya produksi menjadi mahal. Kebun yang sudah tua umumnya memiliki kerapatan tanaman yang rendah, sehingga tanaman dengan kerapatan yang rendah tidak ekonomis untuk dikelola dan perlu dilakukan peremajaan. Sistem peremajaan tanaman kelapa sawit secara umum ada empat macam, yaitu sistem tumbang serempak, sistem underplanting, sistem peremajaan bertahap, dan sistem tumpang sari (intercropping).Keempat sistem tersebut memiliki keunggulan dan kelemahan.

Keunggulan sistem tumbang serempak adalah persiapan lahan dan pengolahan tanah dapat dilakukan lebih intensif, sehingga dapat mengurangi tingkat serangan hama dan penyakit serta menyediakan kondisi tanah yang ideal bagi pertumbuhan tanaman kelapa sawit. Akan tetapi sistem ini dapat menyebabkan hilangnya pendapatan petani karena pendapatan produksi dan penjualan tandan buah segar (TBS) terputus. Sementara itu, sistem underplanting masih memberikan kesempatan bagi petani untuk memperoleh pendapatan dari tanaman tua yang belum ditumbang. Namun demikian, penerapan sistem ini dapat menyebabkan terganggunya pertumbuhan tanaman muda, meningkatnya serangan hama dan penyakit. Pada sistem peremajaan bertahap, petani masih memperoleh pendapatan dari produksi tanaman tua yang belum diremajakan.Akan tetapi sistem ini kurang efektif apabila diterapkan pada luasan lahan yang kecil, seperti kebun plasma dan swadaya. Disisi lain, sistem tumpang sari (intercropping) memberikan alternatif pendapatan melalui produksi tanaman sela, pertumbuhan tanaman muda tidak terganggu, serta residu tanaman sela diharapkan dapat menjadi sumber bahan organik dan membantu suplai hara bagi tanaman muda. Namun demikian, sistem ini memerlukan pengelolaan tanaman sela secara intensif dan memerlukan teknik dan rantai pemasaran yang tepat agar produksi tanaman sela dapat terserap pasar. Kegiatan peremajaan pada kebun plasma dan swadaya dapat menyebabkan terhentinya pendapatan petani. Oleh sebab itu, kegiatan peremajaan kelapa sawit harus mempertimbangkan kelangsungan pendapatan petani dan juga mempertimbangkan efisiensi biaya.

Kegiatan FGD dilakukan untuk menjaring masukan dan ide dari para expert terkait skema pola peremajaan kelapa sawit tersebut. Berdasarkan hasil FGd diperoleh bahwa terdapat 4 skema pola peremjaaan kelapa sawit bagi pekebun swadaya. Selama ini pekebun sulit untuk melakukan peremjaan bukan hanya karena factor biaya tetapi lebih kepada jaminan ekonomi dan social selama melakjkan peremajaan terutama pada masa Tanaman Belum Menghasilkan (TBM). Walaupun pemerintah memberikan bantuan dana BPDPKS sebesar 25 juta tidak menjamin pekebun akan serta merta menerima tawaran tersebut. Berdasarkan survey lapangan di desa sungai Sahut kecamatan Tabir Selatan Kabupaten Merangin diperoleh bahwa rata rata petani yang sudah melakukan peremajaan adalah pekebun yang tidak memiliki hutang, pekebun memiliki lahan kelapa sawit yang lain untuk dipanen, dan tidak mempunyai banyak tanggungan kelauarga selama masa peremajaan.Pekebun yang tidak atau belum melaksanakan peremajan biasanya menghadapi beberapa kendala seperti, masih adanya hutang atau keberadaan sertifikat yang masih dijaminkan di perbankan. Kedua adalah kendala besarnya kebutuhan biaya untuk peremanajan. Biaya 
peremajaan yang cukup tinggi menjadi kendala utama yang dihadapi petani. Menurut informasi yang diperoleh dari pihak yang berkompeten pada organisasi koperasi ini, biaya replanting sesuai RAB yang dibuat oleh pihak Dinas Perkebunan Provinsi sekitar Rp 58.000.000/Ha, artinya dalam satu kapling yang luasnya $2 \mathrm{Ha}$ akan menghabiskan anggaran kurang lebih Rp. 116.000.000; ditambah bunga bank sesuai besarnya pinjaman. Biaya tersebut merupakan biaya yang sangat besar yang harus ditanggung oleh petani dalam proses peremajaan kebun kelapa sawit miliknya. Hal ini menjadi kendala dalam pelaksanaan program peremajaan sebab selain petani tidak memiliki anggaran sebesar itu, juga sulitnya mencari pihak perbankan yang sanggup membiayai dana tersebut dimana pengembaliannya menunggu 4 sampai 5 tahun setelah tanaman kelapa sawit menghasilkan.

Kendala selanjutnya adalah biaya hidup yang cukup besar selama masa TBM. Biaya hidup petani disaat kebun belum diremajakan dan semasa kebun diremajakan sama saja besarnya, bahkan ada kecendrungan mengalami peningkatan seiring terjadinya inflasi dari tahun ke tahun. Pada saat tanaman sawit masih berdiri atau belum diremajakan petani umumnya berpenghasilan 2 sampai 3 juta rupiah per kapling perbulan, kemudian menjadi penghasilan 0 rupiah pada saat tanaman diremajakan. Hal ini menjadi kendala yang sangat serius karena berhubungan dengan kebutuhan pokok petani sehari-hari, belum lagi petani harus mempersipakan biaya untuk peremajaan kebun kelapa sawit miliknya. Banyaknya kendala yang dihadapi menjelang kegiatan peremajaan serta masa peremajaan, dari hasil FGD diperoleh bahwa terdapat 4 skema pola peremajaan kelapa sawit bagi pekebun swadaya di Provinsi Jambi.

\section{Pola Kemitraan}

Pola ini meupakan pola yang ditawarkan kepada pekebun berdasarkan hasil FGD. Dimana pekebun bermitra dengan pihak lain, misalnya perusahaan, yang membantu menyediakan input dan sarana produksi lainnya. Tetapi dalam pelaksanaannya kemitraan ini dilakukan dengan syarat bahwa perhitungan biaya peremajaan dilakukan secara bersama dan transparan. Kedua perlu adanya penguatan kelembagaan, biaya peremjaan hanya terbatas pada biaya bantuan dari BPDPKS, dan terakhir adalah perlunya pendampingan selama masa peremajaan. Jlka asumsi ini dilaksanakan seyogyanya peremajaan tidak perlu ditunggu lagi. Pekebun dapat melakukan peremjaan tanpa perlumerasa khawatir dengan kendala seperti disebutkan di atas.

\section{Pola Swadaya Murni}

Pola swadaya murni ini banyak ditemukan di Kabupaten Muaro Jambi Kecamatan Sungai bahar, dimana pekebun yang melakukan peremajaan merupakan pekebun eks plasma yang telah memiliki pengetahuan dalam usaha tani kelapa sawit, serta kesadaran yang tinggi untuk keberlanjutan perkebunan kelapa sawit mereka. Pola ini, tidak menunggu bantuan pemerintah dimana pemenuhan kebutuhan biaya untuk peremajaan dilakukan oleh pekebun secara swadaya, karena pekebun memiliki sumber daya lain bila melakukan peremajaan untuk menghindari kendala selama masa peremajaan, terutama kehilangan pendapatan. Pola swadaya murni ini juga dapat dijadikan alternative dengan catatan bahwa pekebun sebaiknya tergabung dalam satu kelembagan misalnya kempok tani. Selain itu pekebun harus bermitra dengan perusahaan/PKS untuk pengadaan bibit dan kepastian pemasaran, mempunyai badan hukum legalitas, dan disalurkan langsung ke pekebun. Perlu adanya pendampingan oleh instansi teknis dan disertai dengan program pendukung keberlanjutan alternatif ekonomi dan tabungan.

\section{Pola dengan Inisiasi Pemerintah}

Pemerintah daerah dimana perkebunan kelapa sawit berada pada dasarnya merupakan institusi yang memfasilitasi pekebun untuk melakukan kegiatan peremajaan. Tetapi pemerintah juga dibatasi dengan waktu dan target yang harus diselesaikan dalam periode tertentu. Seringkali satu kegiatan berakhir tanpa keberlanjutan karena dana tidak mendukung lagi untuk tahun selanjutnya. Pola peremajaan dengan inisiasi pemerintah dapat dilakukan dengan mengadopsi pola kemitraan seperti perusahaan dengan pekebun. Pemerintah sebagai lembaga pendukung dapat menjadi mediator sekaligus bagi pekebun dengan penyandang dana seperti perbankan. Keterbatasan akses informasi yang dimiliki pekebun juga merupakan salah satu alasan pekebun belum melakukan peremajaan. Kegiatan sosialisasi dan bimbingan teknis juga seabaiknya rutin dilakukan untuk menambah pengetahun bagi pekebun. 


\section{Pola Koperasi}

Pola koperasi ini merupakan pola yang sudah lama dilakukan oleh para pekebun dalam kegiatan usaha tani kelapa sawit. Tetapi pengalamana dengan koperasi yang tidak baik, dapat menyebabkan keengannan petani untuk bergabung dalam kelembagaan. Hasil survey terhadap 640 pekebun kelapa sawit di 8 kabupaten diperoleh bahwa hanya 34,84 persen yang bergabung dalam kelmabhaan terutama koperasi. Hal ini mengindikasikan masih lemahnya kepercayaan pekebun terhadap keberadaan koperasi. Kelembagaan pekebun dipedesaan berkontribusi dalam akselerasi pembangunan sosial ekonomi pekebun, aksesibilitas pada informasi pertanian, aksesibilitas pada modal, infrastruktur, pasar dan adopsi inovasi-inovasi pertanian. Disamping itu, keberadaan kelembagaan petani akan memudahkan bagi pemerintah dan pemangku kepentingan lain dalam memfasilitasi dan memberikan penguatan pada pekebun Pentingnya kelembagaan pekebun diakui dalam pembangunan pertanian, baik di negara industri maupun negara sedang berkembang seperti Indonesia.

Namun kenyataan memperlihatkan kecenderungan masih lemahnya kelembagaan petani dan besarnya hambatan dalam menumbuhkan kelembagaan pada masyarakat pekebun. Upaya meningkatkan produktivitas, efisiensi usahatani, dan daya saing pekebun dilakukan melalui pengembangan kelembagaan pertanian, termasuk di dalamnya penguatan kapasitas kelembagaan pekebun Kegiatan usaha pertanian akan berhasil jika pekebun mempunyai kapasitas yang memadai. Untuk dapat mencapai produktivitas dan efisiensi yang optimal petani harus menjalankan usaha bersama secara kolektif. Untuk keperluan ini diperlukan pemahaman mengenai suatu kelembagaan ditingkat petani. Kelembagaan pekebun yang dimaksud dalam penelitian ini adalah lembaga petani yang berada pada kawasan lokalitas (local instution), yang berupa organisasi keanggotaan (membership organization) atau kerjasama (cooperatives) yaitu pekebun kelapa sawit swadaya yang tergabung dalam kelompok kerjasama. Kelembagaan merupakan keseluruhan pola-pola ideal, organisasi, dan aktivitas yang berpusat di sekeliling kebutuhan dasar. Suatu kelembagaan pertanian dibentuk selalu bertujuan untuk memenuhi berbagai kebutuhan pekebun sehingga lembaga mempunyai fungsi.

\section{KESIMPULAN}

Skema pola peremajaan kelapa sawit pekebun swadaya yang berkelanjutan terdapat 4 pola alternatif yaitu Pola Kemitraan, pola swadaya murni, pola dengan inisiasi Pemerintah, dan pola koperasi. Setiap pola memiliki kelebihan dan kelebihan masing masing. Pekebun perlu untuk melakukan penguatan kelembagan dalam suatu kelompok dalam melakukan kegiatan peremajaan kelapa sawit agar berkelanjutan.

\section{DAFTAR PUSTAKA}

Adekunle. AA, J Ellis-Jones, I Ajibefun, RA Nyikal, S Bangali, O Fatunbi and A Ange. 2012. Agricultural innovation in sub-Saharan Africa: Experiences from Multiple-stakeholder Approaches. Ghana: Forum for Agricultural Research in Africa (FARA), Accra.

Bourke, R, and Preston, I. 2009. Food And Agriculture in Papua New Guinea, ANU Press, Canberra

Clough, $Y$ et al. 2016. Land Use Choices Folow Profitability at The Expense of Ecological Functions in Indonesia Smallholders Landscapes. Nature Communication 7: 13137- 13149.

Dinas Pertanian 2000. Panduan Rice Estate and Corporate Farming. Bandung. Dinas

perkebunan. 2018. Statistik Perkebunan. Provinsi Jambi

Dinas Perkebunan. 2019. Kegiatan PSR di Provinsi Jambi. Tidak dipublikasikan.

Direktorat Jendral perkebunan, 2018. Statistik Perkebunan Indonesia. Kementerian Pertanian. Jakarta.

Euler, M. 2016. Oil Palm Expansion Among Smallholders Farmers in Sumatra, Indonesia. Journal of Agricultural Economics 67(3): 658-676

Gatto, M et al. 2017. Oil Palm Boom, Contract Farming, and Rural Economic Development: Village level Evidence From Indonesia. World developmet 95: 127-140

Gibbs, H.K et al. 2010. Tropical Forest were the Primary Sources of New Agricultural Laind in the 1980s and 1990s. Proceeding of The National Academy of Sciences of The United States of America 107(38): 16732-16737 
Krishna, V. 2017. Differential Livelihood Impacts of Oil Palm Expansion in Indonesia. Agricultural Economics 48(5): 639-653

Nwachukwu. 2008. Planning and evaluation of agricultural and rural development project. Lambhouse publishers. p. 1-6.

Saleh, R. Gozali dan Zaini. 2007. Analisis Kelembagaan Sistem Integrasi Padi Ternak. http://www.Bp2tp.litbang.deptan.go.id/

Salikin, Karwan A. 2003. Sistem Pertanian Berkelanjutan. Yogyakarta: Kanisius 